\title{
Insulin Resistance, Impaired Postprandial Lipid Metabolism and Abdominal Obesity
}

\author{
A Deadly Triad \\ Keith N. Frayn \\ Oxford Centre for Diabetes, Endocrinology and Metabolism, University of Oxford, UK
}

\section{Key Words}

Coronary heart disease - Postprandial lipaemia . Insulin resistance - Dyslipidaemia - Abdominal obesity

\begin{abstract}
Objective: To review three 'emerging risk factors' for coronary heart disease, the physiological and pathophysiological mechanisms involved, and their inter-relationships. Background: Classical risk factors for coronary heart disease cannot adequately explain the high incidence of this disease. Abdominal obesity and impaired postprandial lipid metabolism have long been recognised as associates of coronary heart disease but only relatively recently has their importance as risk markers been established. Insulin resistance is now often seen as a common theme underlying many factors predisposing to coronary heart disease (CHD). Mechanisms: The mechanisms by which each of these markers relates to coronary heart disease may have common aspects. Specifically, they are all associated with a characteristic dyslipidaemia involving elevation of plasma triacylglycerol concentrations, reduction of high-density lipoprotein cholesterol (HDL-cholesterol) and the presence of small, dense low-density lipoprotein particles that may carry particular risk of atherogenesis. Insulin resistance is also
\end{abstract}

associated with hypertension and impairment of endothelial function, and with a procoagulant state. Treatment: No specific or separate pharmacological treatment of any of these conditions separately has been shown to reduce the risk of CHD although each can be manipulated. Lifestyle modification, with increased physical activity and dietary change, may offer the best hope of primary prevention but to achieve this, interventions at government level rather than advice from individual physicians would probably be required. Conclusions: Abdominal obesity, impaired postprandial lipid metabolism and insulin resistance are all inter-related risk markers for CHD. They seem to reflect lifestyle in the developed and developing worlds and perhaps modification of lifestyle holds the greatest hope for their amelioration in the future.

Copyright $\odot$ 2002S. Karger AG, Base

\section{Introduction}

It has become increasingly clear that classical risk factors (listed in table 1) cannot explain the large number of cases of coronary heart disease (CHD) seen in developed or developing countries. For example, the distribution of plasma cholesterol concentrations in those who developed

\begin{tabular}{ll}
\hline KARGER & ( ) 2002 S. Karger AG, Basel \\
Fax +4161306 1234 $3411-7571 / 02 / 0116-0031 \$ 18.50 / 0$ \\
$\begin{array}{l}\text { E-Mail karger@karger.ch } \\
\text { www.karger.com }\end{array}$ & $\begin{array}{l}\text { Accessible online at: } \\
\text { www.karger.com/mpp }\end{array}$
\end{tabular}

Prof. Keith N. Frayn

Oxford Lipid Metabolism Group

Radcliffe Infirmary

Oxford, OX2 6HE (UK)

Tel. +44 1865 224180, Fax +44 1865 224652, E-Mail keith.frayn@oxlip.ox.ac.uk 
Table 1. Classical and emerging risk factors for coronary heart disease

Table 2. Characteristics of the insulin resistance syndrome

\begin{tabular}{ll}
\hline 'Classical' & 'Emerging' \\
\hline Lipids & Lipids \\
$\quad$ Elevated total cholesterol & Exaggerated postprandial lipaemia \\
Elevated LDL-cholesterol & Small, dense LDL particles \\
$\quad$ Low HDL-cholesterol & Lp(a) \\
Elevated fasting TG & Coagulation-related factors \\
Smoking & (including fibrinogen, PAI-1, fibrin D-dimers) \\
Hypertension & Insulin resistance \\
Male gender & Endothelial dysfunction \\
Ethnicity & Markers of inflammation (including CRP) \\
Age & Chronic infection \\
Family history & (Helicobacter pylori, Chlamydia pneumoniae) \\
Diabetes mellitus & Elevated homocysteine concentration \\
Obesity & Abdominal obesity \\
\hline
\end{tabular}

The table is not intended to be exhaustive and the distinction between 'classical' and 'emerging' risk factors is necessarily rather subjective.

This table is based upon the original description by Reaven [70] but it has been expanded since by many authors $[73,81,98]$.

Reproduced from Frayn [99].

CHD overlaps closely with the distribution in those who remained disease-free in several large prospective studies $[1,2]$. Therefore, there is increasing interest in identification of additional, non-classical, risk markers. A large number of new, 'emerging' risk markers has now been identified (table 1). In this review, only three of these will be discussed, namely impaired postprandial lipid metabolism (exaggerated postprandial lipaemia), upper body fat distribution (or abdominal obesity) and insulin resistance. These three are not independent, and insulin resistance may well be a common underlying basis not just of the other two markers described here, but also of others listed in table 2 .

\section{Impaired Postprandial Lipaemia}

\section{History of Recognition as a Risk Marker for CHD}

The classical lipid risk factors for CHD (table 1) are based on measurements made in the fasting state. Elevated fasting low-density lipoprotein-cholesterol (LDLcholesterol) concentrations and low HDL-cholesterol concentrations are well-recognised markers of increased CHD risk. Fasting plasma triglyceride (TG) concentrations are a risk marker for CHD [3], although in many studies it is described as only a relatively weak marker because of a strong inverse relationship between TG and HDL-cholesterol concentrations. HDL-cholesterol con- 
centrations are more stable from day to day in any one individual, and because of this they tend to 'win' statistically when both HDL-cholesterol and TG concentrations are entered into multivariate analyses [3]. Recently, the nature of the LDL particles has been recognised as important: people who have a predominance of small, dense (lipid-depleted) LDL particles are at increased risk of CHD compared to those with larger, more lipid-rich LDL particles $[4,5]$. Each particle of LDL carries one molecule of the large apolipoprotein B100 (apoB100), so that plasma apoB100 concentrations are an indicator of the number of LDL particles. Plasma apoB100 especially in conjunction with LDL particle size and fasting insulin has been shown to be a strong indicator of CHD risk (see below) [6].

It has long been suggested, however, that events occurring in the period following a meal (the postprandial period) may be of particular significance for the development of atherosclerosis. Moreton [7] in 1947 showed 'sustained hyperlipaemia', assessed from the turbidity of plasma following an oral fat load, in subjects with atherosclerosis, and concluded that 'the cumulative effect of many fatty meals over a lifetime ... may be the underlying cause of the intimal lipid deposition in human atherosclerosis'. Becker et al. [8] in 1949 showed a prolonged and exaggerated appearance of chylomicrons (carrying dietary fat) in the circulation following an oral fat load, in older compared to younger subjects; they concluded that the vascular wall in older people would be almost continually exposed to dietary fat, and that 'the condition leading to that degenerative disease [atherosclerosis] has been found'. More than 20 years ago Zilversmit [9] proposed that atherogenesis was a postprandial phenomenon. By this he implied that remnants of lipoprotein particles involved in the response to a meal might have atherogenic effects on the vasculature.

\section{Physiological Mechanisms Underlying Postprandial Lipid Metabolism}

These early studies focussed attention on the events that occur in the postprandial period. When a healthy person eats a meal that contains fat, there is a relatively slow rise in plasma TG concentration (compared with the rise in glucose concentration), peaking typically at 3-5 h following the meal. Plasma TG concentrations then decline and return towards baseline. The response to eating a fatty meal may be defined in terms of the rise in plasma TG concentration, or 'postprandial lipaemia'. This is measured as the area under the TG-time curve (usually above the baseline level), or the TG concentration at later time points. Several cross-sectional or case-control studies show that CHD is associated with increased postprandial lipaemia [10-14]. The link between impaired postprandial lipid metabolism and atherosclerosis seems to involve prolonged residence of small remnant particles in the circulation $[15,16]$. Therefore, it is important to understand the events that occur in the postprandial period, how they may influence CHD risk, and how they may be modified.

On a typical Western-style diet, most people eat around $100 \mathrm{~g}$ of fat each day, mostly in the form of triacylglycerol (TG), and $300 \mathrm{~g}$ carbohydrate. A typical meal might contain $30-40 \mathrm{~g}$ fat and $100 \mathrm{~g}$ carbohydrate. It is useful initially to consider glucose metabolism in the postprandial period, since this is well understood and widely accepted. The amount of free glucose in the body (vascular plus extravascular glucose space) is very small, typically $12 \mathrm{~g}$. Therefore, ingestion of $100 \mathrm{~g}$ carbohydrate has the potential to cause a major disturbance in blood glucose concentration (an eightfold rise). This does not happen because co-ordinated mechanisms come into play to increase glucose disposal from the plasma and suppress the entry of endogenous glucose [17]. Insulin is a major determinant of these responses, and in insulin resistance or insulin deficiency (e.g. in diabetes mellitus) the postprandial excursion in glucose concentration is exaggerated.

Exactly the same arguments can be made for lipid metabolism. The amount of TG in the circulation is very small, typically $3 \mathrm{~g}$ (with a plasma TG concentration of $1 \mathrm{mmol} / \mathrm{l})$. Therefore, when $30-40 \mathrm{~g}$ fat is ingested, there is the potential for a large excursion in plasma TG concentration. In fact in normal, healthy subjects eating such a meal (33 g fat, $96 \mathrm{~g}$ carbohydrate) the plasma TG concentration on average increases twofold at peak [18]; it does not increase tenfold. Therefore, we may suppose that coordinated mechanisms must come into play to minimise the excursion in plasma TG concentration. Again, also, insulin appears to play a major role. The major mechanisms that minimise excursions in plasma TG concentrations in the postprandial state, so far as they are understood, include: (a) up-regulation by insulin of lipoprotein lipase in adipose tissue; (b) suppression of the release of non-esterified fatty acids (NEFA) from adipose tissue, and (c) suppression by insulin of hepatic very-low-density lipoprotein (VLDL)-TG secretion (fig. 1).

When there is an impairment of postprandial lipid metabolism, it is reasonable to suppose that the normal co-ordinated mechanisms regulating lipid metabolism have become disturbed. A clear example is in insulin resistance (see below, under 'Insulin Resistance') when 
Fig. 1. Normal coordination of postprandial lipid metabolism by insulin. Insulin, secreted in response to the carbohydrate and protein contents of a mixed meal, has powerful effects on lipid metabolism. These include activation of adipose tissue lipoprotein lipase (LPL), suppression of non-esterified fatty acid release from adipose tissue and (probably, although not convincingly shown in vivo) suppression of hepatic secretion of very-low-density lipoprotein (VLDL)-triacylglycerol. IDL $=$ Intermediate-density lipoprotein; LDL = low-density lipoprotein.

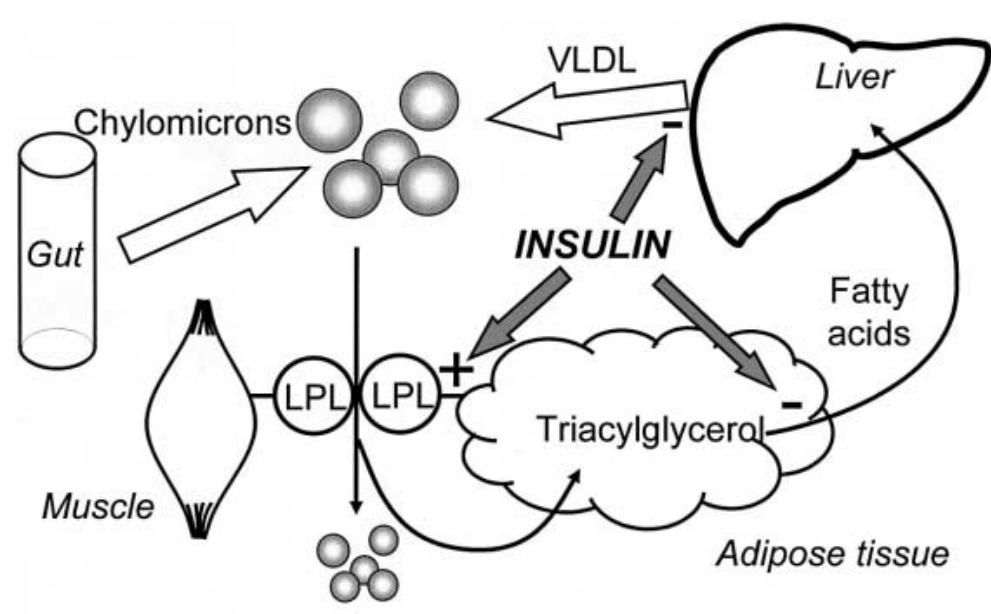

Chylomicron remnants, IDL, LDL each of the three processes mentioned above becomes 'insulin resistant' with the result that the postprandial excursion in plasma TG concentration is increased [19]. Other abnormalities might be caused by impairment of the receptor-mediated removal of remnant particles from the circulation. Although there is still controversy about the nature of the 'chylomicron remnant receptor', it is probable that the LDL-receptor-related protein (LRP) plays a major role in this process. In principle, then, impairment of LRP function might lead to delayed removal of TGrich remnants, although this has not been shown in practice.

\section{Pathophysiology}

The effects of delayed removal of TG-rich lipoproteins in the postprandial period may be widespread. The action of the cholesteryl ester transfer protein (CETP) is normally a beneficial part of the process of reverse cholesterol transport - transport of excess cholesterol to the liver for excretion. When there is an expanded pool of TG-rich lipoproteins, as in the case of increased postprandial lipaemia, then CETP will mediate the exchange of TG from these particles with cholesteryl ester from the cholesterol-rich lipoproteins, LDL and HDL. The result is that the remnants formed from VLDL and chylomicron metabolism are enriched in cholesterol. It has been suggested that this makes these remnant particles more atherogenic. There is continuing debate about whether the chylomicron remnants themselves might be deposited in the arterial wall to begin the process of atherogenesis [20,21].
Better established are the effects on LDL and HDL. Through the action of CETP, these particles have now become depleted of cholesteryl ester but enriched with TG. Their TG is a substrate for hydrolysis by the enzyme hepatic lipase. The result is LDL and HDL particles that have become depleted of lipid - so-called small, dense LDL particles, and a low HDL-cholesterol concentration (fig. 2). As noted earlier, these are aspects of the atherogenic lipoprotein phenotype that is strongly predictive of CHD risk [22, 23].

As discussed in more detail later (under 'Insulin Resistance'), plasma NEFA may play a role in the adverse effects of impaired postprandial lipid metabolism. Failure of insulin to suppress plasma NEFA concentration normally may result in a greater drive for hepatic VLDL-TG secretion. VLDL particles compete with chylomicrons for TG clearance by lipoprotein lipase in peripheral tissues [24], so this can accentuate lipaemia. In addition, NEFA increase the activity, and possibly the mass, of CETP in plasma $[25,26]$, and will therefore accentuate the dyslipidaemia resulting from increased postprandial lipaemia.

\section{Modification of Postprandial Lipaemia}

What treatments can improve postprandial lipid metabolism? The weight-reducing drug orlistat (Xenical, Roche) inhibits pancreatic lipase in the small intestine and therefore reduces absorption of dietary fat. Orlistat should therefore be the perfect drug to lower postprandial TG concentrations. In one study in which this was tested, however, it was not found to do so [27]. The fibrate hypo- 
Fig. 2. Role of cholesteryl ester transfer protein (CETP) in the generation of an atherogenic lipoprotein phenotype. The events are described in more detail in the text. TG = Triacylglycerol; LPL = lipoprotein lipase; LDL = low-density lipoprotein; VLDL = very-low-density lipoprotein. Reproduced from Frayn [100].

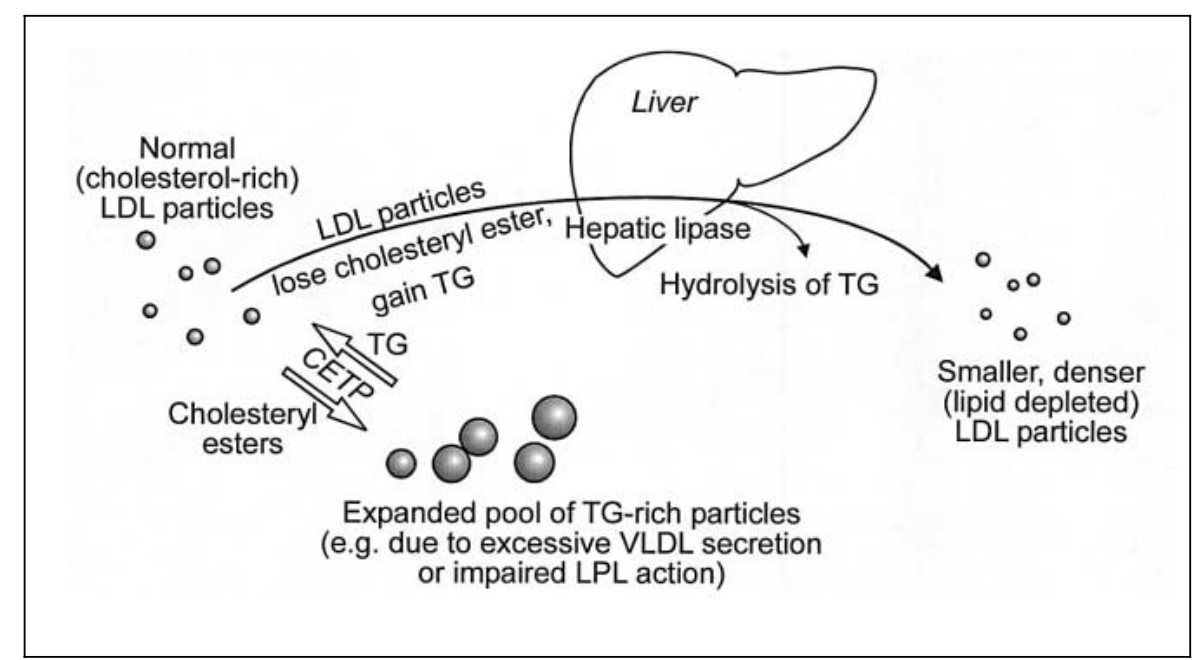

lipidaemic drugs have potent effects in reducing postprandial lipaemia [28]. The HMG-CoA reductase drugs ('statins') also have a significant effect, which is of the same order of magnitude as their effect on fasting TG concentrations [29].

Lifestyle modifications can certainly be of benefit. The best documented such change is physical activity. A welltrained athlete has extremely good lipid tolerance, although this capacity is lost rapidly when training is interrupted [30]. A single bout of physical activity will markedly improve postprandial lipid metabolism when tested the following day [31], although again this effect is lost within a few days [32, 33]. Regular physical activity, known in any case to reduce CHD risk [34], is therefore a means of beneficially modifying postprandial lipid metabolism, as well as reducing abdominal fat and improving sensitivity to insulin.

\section{Abdominal Obesity and CHD Risk}

\section{History}

It was noted by Jean Vague, working in Marseilles, France in the 1940s, that obesity could be sub-divided into upper-body, masculine-type obesity, which he called android obesity, and lower-body, female-type fat distribution that he called gynoid obesity [35]. Vague also noted that the former tended to be associated with diseases including diabetes, atherosclerosis and gout [36].

Many studies have confirmed the association between upper-body fat distribution and markers of CHD risk, including reduced HDL-cholesterol and moderately ele- vated TG concentrations: in fact, the typical dyslipidaemia associated with insulin resistance as reviewed in $[37,38]$. Some prospective studies have shown a link between fat distribution (usually measured as the simple surrogate of waist to hip circumference ratio) and presence of CHD [39], or mortality from CHD [40-42]. The prevalence of abdominal obesity may explain, at least in part, the high incidence of CHD in certain ethnic groups such as South Asians [43].

\section{Physiological Mechanisms}

What is the mechanism by which upper-body obesity leads to insulin resistance, dyslipidaemia and increased risk of CHD? This is usually ascribed to the characteristic metabolic features of upper-body (abdominal) adipose tissue compared with lower-body (gluteal and femoral). When adipocytes are isolated from these depots and studied in vitro, consistent differences are found. Gluteal/ femoral adipocytes are characterised by relatively low rates of lipolysis, with a low sensitivity to stimulation by $\beta$-adrenergic agonists [44]. In contrast, the ability of insulin to suppress lipolysis in lower-body adipocytes is high [45]. These adipocytes from the lower body seem to be specialised in retaining fatty acids, and resistant to releasing them. Adipocytes from the upper body, in contrast, respond more readily to stimulation of lipolysis, and lipolysis when stimulated is less readily suppressed by insulin [44-46]. Intra-abdominal adipocytes (especially those from the omental and mesenteric depots) show a particularly high rate of lipolysis in vitro [45, 46]. This difference is particularly marked in males [47]. Upper-body adipocytes, then, in comparison with those of the lower body, 
are more metabolically active, and tend to release fatty acids more readily. It is then assumed that a greater rate of delivery of non-esterified fatty acids (NEFA, also called free fatty acids, FFA) into the circulation, from those with upper-body obesity compared with those with lower-body fat accumulation, may account for many of the differences in CHD risk. The detrimental effects of elevated NEFA concentrations on CHD risk are discussed in more detail below (under 'Insulin Resistance').

This hypothesis also neatly fits with the commonlyobserved relative protection of pre-menopausal women from CHD compared with men: in general, women tend to have more lower-body fat than men. In fact, it has been suggested that differences between men and women in (postprandial) lipid metabolism disappear when adjusted for body fat distribution [48].

Abdominal obesity involves both subcutaneous and intra-abdominal fat accumulation [49]. There has been much debate about whether the intra-abdominal (or visceral) fat depots (mainly omental, mesenteric and perirenal) play a special role in the increased risk of CHD. Evidence for this comes from many studies in which the different depots have been measured by computed tomography or magnetic resonance imaging $[50,51]$. However, other studies suggest than the subcutaneous abdominal depots are more important [52], and yet further studies show both intra-abdominal and subcutaneous abdominal depots to relate to aspects of insulin resistance [53-55]. This is a difficult matter to decide, because the two (intraabdominal and subcutaneous abdominal depots) are closely correlated as reviewed in [56]: it is unusual to find accumulation of subcutaneous fat without accompanying intra-abdominal fat, and vice versa. It should be noted in passing that studies such as these have also shown lowerbody fat depots to be protective against CHD [55, 57].

The special role attributed by many to intra-abdominal depots may have a mechanistic basis. Most of the omental and mesenteric depots liberate their NEFA directly into the portal vein, and so they may have direct effects on liver metabolism (including stimulation of glucose production and of VLDL-TG secretion). This hypothesis for the link between abdominal fat deposition and CHD risk has been called the 'portal theory' $[56,58]$. However, this theory is based almost entirely on studies conducted in vitro, and a critical review of the evidence [56] suggests that it is likely that the totality of abdominal adipose tissue, which is both subcutaneous and intra-abdominal, is responsible for the abnormalities, by secretion of NEFA at a higher rate than would be typical for lower-body adipose tissue.

\section{Possible Treatment}

It is important to ask what can be done to reduce central obesity in order to reduce CHD risk. Weight loss by dieting leads to loss of abdominal (intra-abdominal and subcutaneous abdominal) fat [59-61]. The only specific treatment, other than surgery, that has consistently been shown to have a selective effect on reducing abdominal fat is physical exercise $[60,62,63]$. In assessing the risk to an individual patient, it is generally accepted that the waisthip ratio is a relatively crude measure: in very obese people both waist and hip expand whilst the ratio may not change. The use of waist circumference has recently been shown to be a useful clinical assessment of CHD risk. It may be used as a ratio to height, to allow for variations in the latter [64], alone as an indicator of need for weight management [65], or with the plasma TG concentration [66]. The use of waist circumference $\geq 90 \mathrm{~cm}$ for men, together with a plasma TG concentration $\geq 2 \mathrm{mmol} / \mathrm{l}$, has shown to be highly discriminatory for the development of CHD.

\section{Insulin Resistance as a Unifying Theme}

\section{Historical Basis of the Concept of Insulin Resistance}

Insulin resistance is defined as a requirement for greater concentrations of insulin than normal to elicit a given metabolic response. The concept of sensitivity to insulin was first proposed by Himsworth [67]. He showed that when he injected insulin, together with glucose, into diabetic patients, some patients showed a fall in plasma glucose concentration while others did not. The insulin-sensitive' patients tended to be thin, with early onset of the disease (what we would now call type 1 diabetes), and the 'insulin-insensitive' patients tended to be overweight with later onset of the disease (type 2 diabetes). It was recognised in the 1960s that insulin resistance is also prominent in non-diabetic obese people [68, 69]. In 1988, Reaven [70] published his seminal paper in which he described insulin resistance as the central feature of a constellation of associated, adverse changes including an adverse lipoprotein profile (moderately elevated triacylglycerol, reduced HDL-cholesterol concentrations) and hypertension, and with increased risk of development of type 2 diabetes and CHD. He coined the term Syndrome $\mathrm{X}$ for this syndrome, and proposed that it was relatively common even amongst non-diabetic, non-obese subjects. It is certainly true that in large, cross-sectional studies, fasting insulin concentrations (a marker of insulin resistance) are associated with these features [71]. The term 
'insulin resistance syndrome' or 'metabolic syndrome' is now more commonly used for this pattern of disease markers. The original list proposed by Reaven has since been expanded and it is now recognised that an important additional factor is a change in the nature of LDL particles, with a predominance of so-called small, dense LDL, although the LDL-cholesterol concentration is usually only slightly raised [72]. The syndrome is also associated with increased postprandial lipaemia [73] (as discussed above) and with a pro-coagulant state, indicated by increased circulating concentrations of the fibrinolytic inhibitor, plasminogen activator inhibitor-1 (PAI-1) [74].

Reaven's suggestions were based mainly on detailed physiological studies. Since then some prospective studies have found that elevated fasting insulin concentrations (as noted above, a marker of insulin resistance) are associated with increased CHD risk [75-80].

\section{Links between Insulin Resistance and CHD}

What is the link between insulin resistance and CHD? It is usually assumed that increased CHD risk is mediated through the associates of insulin resistance listed in table 2. Evidence from prospective studies suggests that there may be a more direct role of insulin resistance, but it is not clear what this might be. Recently, evidence has accumulated suggesting a role for impairment of endothelial function in insulin resistance [81]. Impaired endothelial function is certainly associated with many traditional risk factors for CHD, including hypercholesterolaemia, hypertension, cigarette smoking, diabetes mellitus, and a high-fat diet [82]. Impaired endothelium function may promote the development of atherosclerosis through its effects on vascular regulation, platelet and monocyte adhesion, vascular smooth muscle cell growth, and coagulation [82].

What is the link between all these different facets of insulin resistance? The most plausible link involves disruption by insulin resistance of the co-ordination of lipid metabolism that occurs in the postprandial period. Insulin normally co-ordinates a number of events during this period and each of these steps can become 'insulin resistant' [19]. The overall effect is a prolongation of postprandial lipaemia, greater exchange of lipids mediated by the cholesteryl-ester transfer protein, loss of HDL-cholesterol and formation of atherogenic small, dense LDL particles $[83,84]$. This was discussed in more detail above.

A further unifying factor in the diverse pattern of adverse changes associated with insulin resistance may be elevation of the plasma concentration of non-esterified fatty acids (NEFA), also called free fatty acids (FFA).
When fat stored in adipose tissue is mobilized, for instance during starvation or during exercise, NEFA are released into the circulation and transported, bound to albumin, to tissues such as skeletal muscle and liver where they may be substrates for oxidation. In addition, in the liver, NEFA may be esterified to glycerol to make TG that is secreted in very-low-density lipoprotein (VLDL) particles. VLDL particles are the precursors of LDL. The release of NEFA from adipose tissue is suppressed by insulin. Therefore, in the period following a meal, when insulin levels are high, plasma NEFA concentrations are usually low thereby reducing competition with glucose for oxidation. It also removes the main substrate for VLDLTG synthesis. There is consistent evidence that insulin resistance, in obesity or in diabetes, for instance, is associated with elevated NEFA concentrations, implying that the effect of insulin on NEFA release from adipose tissue also becomes 'resistant' [85-87]. In particular, resistance of NEFA concentrations to suppression by insulin seems to be associated with increased CHD risk [88, 89]. There are many reasons why elevated NEFA concentrations, especially in the postprandial period, might have this effect. These include adverse effects on endothelial function $[90,91]$ and potentiation of the activity of the cholesteryl ester transfer protein (CETP), which is responsible for the formation of small, dense LDL particles and for loss of HDL-cholesterol [25, 26].

\section{Possible Modification of Insulin Resistance}

In view of the strong evidence for insulin resistance as a risk marker for CHD, it is important to ask whether it can be modified. The new thiazolidinedione anti-diabetic drugs (troglitazone, rosiglitazone, pioglitazone) are marketed as insulin-sensitizers. There is as yet no prospective evidence as to whether they will reduce CHD incidence. Lifestyle modifications that favourably influence insulin resistance are weight loss and increased physical activity. Since both obesity [92] and a sedentary lifestyle [34, 93] are known to increase CHD risk, these changes may bring important benefits. Recently, evidence has accumulated that a diet in which polyunsaturated fatty acids, particularly those of the n-3 variety, replace saturated fatty acids can improve insulin sensitivity as reviewed in [94, 95]. A diet of low glycaemic index, rich in complex carbohydrates rather than simple sugars, has also been shown to improve sensitivity to insulin [96]. Therefore, a prudent diet and regular exercise may exert beneficial effects on insulin resistance, and hence on risk of type 2 diabetes and CHD. 


\section{Conclusion}

Classical risk factors for CHD are insufficient to explain the high incidence of the disease. Amongst more recently identified risk markers are impaired postprandial lipid metabolism (in fact this was identified as early as 1947 but has only relatively recently received much attention), an upper-body fat distribution (also first recognised in 1947) and insulin resistance. In fact these three markers are all associated, making the determination of cause and effect difficult. The case being developed above is that impairment of postprandial lipid metabolism is the 'final common pathway' leading to CHD. However, this is certainly arguable. Insulin resistance is also associated with a pro-coagulant state and impairment of endothelial function, and plausible links exist between both these and hypertension, CHD and myocardial infarction. Kaplan has described as 'the deadly quartet' the combination of upper-body obesity, glucose intolerance, hypertriglyceridaemia, and hypertension [97]. It seems unlikely that we will ever fully disentangle cause and effect amongst these, but they certainly form a powerful constellation of risk markers. Although mortality from CHD can be reduced by lowering of cholesterol and TG concentrations with statins and fibrates, the most physiological means for reducing the impact of this deadly quartet is certainly a combination of increased physical activity and a prudent diet. However, the reduction in risk achievable by lifestyle modification in those with established CHD is probably small; but perhaps there is still hope for benefits in primary prevention of CHD. To achieve real benefits, however, will require more than advice from physicians: it will require changes in government policies to encourage physical activity and reduce reliance on the motor car.

\section{References}

1 Wald NJ: Cholesterol and coronary heart disease: To screen or not to screen; in Marmot M, Elliott P (eds): Coronary Heart Disease Epidemiology: From Aetiology to Public Health. Oxford, Oxford Medical Publications, 1992.

2 Després JP, Lemieux I, Dagenais GR, Cantin B, Lamarche B: HDL-cholesterol as a marker of coronary heart disease risk: The Québec cardiovascular study. Atherosclerosis 2000;153. 263-272.

3 Hokanson JE, Austin MA: Plasma triglyceride level is a risk factor for cardiovascular disease independent of high-density lipoprotein cholesterol level: A meta-analysis of populationbased prospective studies. J Cardiovasc Risk 1996;3:213-219.

4 Austin MA, Breslow JL, Hennekens CH, Buring JE, Willett WC, Krauss RM: Low-density lipoprotein subclass patterns and risk of myocardial infarction. Jama 1988;260:1917-1921.

5 Gardner CD, Fortmann SP, Krauss RM: Association of small low-density lipoprotein particles with the incidence of coronary artery disease in men and women. JAMA 1996;276:875881

6 Lamarche B, Tchernof MA, Mauriège P, Cantin B, Dagenais GR, Lupien PJ, Després JP: Fasting insulin and apolipoprotein B levels and low-density lipoprotein particle size as risk factors for ischemic heart disease. JAMA 1998 279:1955-1961.

7 Moreton JR: Atherosclerosis and alimentary hyperlipemia. Science 1947;106:190-191.

8 Becker GH, Meyer J, Necheles H: Fat absorption and atherosclerosis. Science 1949;110: 529-530.

9 Zilversmit DB: Atherogenesis: A postprandial phenomenon. Circulation 1979;60:473-485.
10 Groot PH, van Stiphout WA, Krauss XH, Jansen $H$, van Tol A, van Ramshorst E, Chin-On S, Hofman A, Cresswell SR, Havekes L: Postprandial lipoprotein metabolism in normolipidemic men with and without coronary artery disease. Arterioscler Thromb 1991;11:653662.

11 Patsch JR, Miesenböck G, Hopferwieser T, Mühlberger V, Knapp E, Dunn JK, Gotto AM Jr, Patsch W: Relation of triglyceride metabolism and coronary artery disease: Studies in the postprandial state. Arterioscler Thromb 1992; 12:1336-1345

12 Karpe F, Olivecrona T, Walldius G, Hamsten A: Lipoprotein lipase in plasma after an oral fat load: Relation to free fatty acids. J Lipid Res 1992;33:975-984.

13 Sharrett AR, Chambless LE, Heiss G, Paton CC, Patsch W: Association of postprandial triglyceride and retinyl palmitate responses with asymptomatic carotid artery atherosclerosis in middle-aged men and women: The atherosclerosis risk in communities (ARIC) study. Arterioscler Thromb Vasc Biol 1995;15:21222129.

14 Boquist S, Ruotolo G, Tang R, Björkegren J, Bond MG, de Faire U, Karpe F, Hamsten A: Alimentary lipemia, postprandial triglyceriderich lipoproteins, and common carotid intimamedia thickness in healthy, middle-aged men. Circulation 1999;100:723-728.

15 Karpe F, Steiner G, Uffelman K, Olivecrona T, Hamsten A: Postprandial lipoproteins and progression of coronary atherosclerosis. Atherosclerosis 1994;106:83-97.

16 Weintraub MS, Grosskopf I, Rassin T, Miller $\mathrm{H}$, Charach G, Rotmensch HH, Liron M, Rubinstein A, Iaina A: Clearance of chylomicron remnants in normolipidaemic patients with coronary artery disease: Case control study over three years. BMJ 1996:312:935-939.
17 Fery F, d'Attellis NP, Balasse EO: Mechanisms of starvation diabetes: Study with double tracer and indirect calorimetry. Am J Physiol 1990 259:E770-E777.

18 Coppack SW, Fisher RM, Gibbons GF, Humphreys SM, McDonough MJ, Potts JL, Frayn KN: Postprandial substrate deposition in human forearm and adipose tissues in vivo. Clin Sci 1990;79:339-348.

19 Frayn KN: Insulin resistance and lipid metabolism. Curr Opin Lipidol 1993;4:197-204.

20 Proctor SD, Mamo JC: Retention of fluorescent-labelled chylomicron remnants within the intima of the arterial wall: Evidence that plaque cholesterol may be derived from postprandial lipoproteins. Eur J Clin Invest 1998; 28:497-503.

$21 \mathrm{Yu} \mathrm{KC,} \mathrm{Mamo} \mathrm{JC:} \mathrm{Chylomicron-remnant-in-}$ duced foam cell formation and cytotoxicity: A possible mechanism of cell death in atherosclerosis. Clin Sci 2000;98:183-192.

22 Austin MA, King MC, Vranizan KM, Krauss RM: Atherogenic lipoprotein phenotype: A proposed genetic marker for coronary heart disease. Circulation 1990;82:495-506.

23 Lamarche B, Després J-P, Moorjani S, Cantin B, Dagenais GR, Lupien PJ: Prevalence of dyslipidemic phenotypes in ischemic heart disease (Prospective results from the Québec Cardiovascular Study). Am J Cardiol 1995;75:1189_ 1195.

24 Brunzell JD, Hazzard WR, Porte D Jr, Bierman EL: Evidence for a common, saturable, triglyceride removal mechanism for chylomicrons and very low density lipoproteins in man. J Clin Invest 1973;52:1578-1585. 
25 Lagrost L, Florentin E, Guyard-Dangremont V, Athias A, Gandjini H, Lallemant C, Gambert P: Evidence for nonesterified fatty acids as modulators of neutral lipid transfers in normolipidemic human plasma. Arterioscler Thromb Vasc Biol 1995;15:1388-1396.

26 Braschi S, Masson D, Rostoker G, Florentin E, Athias A, Martin C, Jacotot B, Gambert P, Lallemant C, Lagrost L: Role of lipoprotein-bound NEFAs in enhancing the specific activity of plasma CETP in the nephrotic syndrome. Arterioscler Thromb Vasc Biol 1997;17:25592567.

27 Shepard TY, Jensen DR, Blotner S, Zhi J, Guerciolini R, Pace D, Eckel RH: Orlistat fails to alter postprandial plasma lipid excursions or plasma lipases in normal-weight male volunteers. Int J Obes Relat Metab Disord 2000;24 187-194.

28 Simpson HS, Williamson CM, Olivecrona T, Pringle S, Maclean J, Lorimer AR, Bonnefous F, Bogaievsky Y, Packard CJ, Shepherd J: Postprandial lipemia, fenofibrate and coronary artery disease. Atherosclerosis 1990;85:193-202.

29 Weintraub MS, Eisenberg S, Breslow JL: Lovastatin reduces postprandial lipoprotein levels in hypercholesterolaemic patients with mild hypertriglyceridaemia. Eur J Clin Invest 1989; 19:480-485

30 Patsch JR, Karlin JB, Scott LW, Smith LC, Gotto AM Jr: Inverse relationship between blood levels of high density lipoprotein subfraction 2 and magnitude of postprandial lipemia. Proc Natl Acad Sci USA 1983;80:14491453.

31 Hardman AE: The influence of exercise on postprandial triacylglycerol metabolism. Atherosclerosis 1998;141(suppl 1):S93-S100.

32 Hardman AE, Lawrence JE, Herd SL: Postprandial lipemia in endurance-trained people during a short interruption to training. J Appl Physiol 1998;84:1895-1901.

33 Herd SL, Hardman AE, Boobis LH, Cairns CJ The effect of 13 weeks of running training followed by 9 days of detraining on postprandial lipaemia. Br J Nutr 1998;80:57-66.

34 Paffenbarger RS Jr, Hyde RT, Wing AL, Lee IM, Jung DL, Kampert JB: The association of changes in physical-activity level and other lifestyle characteristics with mortality among men. N Engl J Med 1993;328:538-545.

35 Vague J: La différenciation sexuelle, facteur déterminant des formes de l'obésité. Presse Méd 1947;30:339-340.

36 Vague J: The degree of masculine differentiation of obesities: A factor determining predisposition to diabetes, atherosclerosis, gout and uric calculous disease. Am J Clin Nutr 1956;4: 20-34.

37 Kissebah AH, Krakower GR: Regional adiposity and morbidity. Physiol Rev 1994;74:761811

38 Brunzell JD, Hokanson JE: Dyslipidemia of central obesity and insulin resistance. Diabetes Care 1999;22(suppl 3):C10-C13.
39 Kortelainen ML, Särkioja T: Extent and composition of coronary lesions in relation to fat distribution in women younger than 50 years of age. Arterioscler Thromb Vasc Biol 1999;19: 695-699.

40 Fontbonne A, Thibult N, Eschwège E, Ducimetière P: Body fat distribution and coronary heart disease mortality in subjects with impaired glucose tolerance or diabetes mellitus: The Paris Prospective Study, 15-year followup. Diabetologia 1992;35:464-468.

41 Folsom AR, Kaye SA, Sellers TA, Hong CP, Cerhan JR, Potter JD, Prineas RJ: Body fat distribution and 5-year risk of death in older women. J Am Med Assoc 1993;269:483-487.

42 Kalmijn S, Curb JD, Rodriguez BL, Yano K, Abbott RD: The association of body weight and anthropometry with mortality in elderly men: The Honolulu Heart Program. Int J Obes Relat Metab Disord 1999;23:395-402.

43 McKeigue PM, Shah B, Marmot MG: Relation of central obesity and insulin resistance with high diabetes prevalence and cardiovascular risk in South Asians. Lancet 1991;337:382386.

44 Rebuffé-Scrive M, Lönnroth P, Mårin P, Wesslau C, Björntorp P, Smith U: Regional adipose tissue metabolism in men and postmenopausal women. Int J Obes 1987;11:347-355.

45 Richelsen B, Pedersen SB, Møller-Pedersen T, Bak JF: Regional differences in triglyceride breakdown in human adipose tissue: Effects of catecholamines, insulin, and prostaglandin $\mathrm{E}_{2}$. Metabolism 1991;40:990-996.

46 Bolinder J, Kager L, Östman J, Arner P: Differences at the receptor and postreceptor levels between human omental and subcutaneous adipose tissue in the action of insulin on lipolysis. Diabetes 1983;32:117-123.

47 Rebuffé-Scrive M, Andersson B, Olbe L, Björntorp P: Metabolism of adipose tissue in intraabdominal depots of nonobese men and women. Metabolism 1989;38:453-458.

48 Couillard C, Bergeron N, Prud'homme D, Bergeron J, Tremblay A, Bouchard C, Mauriège $\mathrm{P}$, Després JP: Gender difference in postprandial lipemia: Importance of visceral adipose tissue accumulation. Arterioscler Thromb Vasc Biol 1999; 19:2448-2455

49 Ashwell M, Cole TJ, Dixon AK: Obesity: New insight into the anthropometric classification of fat distribution shown by computed tomography. Br Med J 1985;290:1692-1694.

50 Després JP, Nadeau A, Tremblay A, Ferland M, Moorjani S, Lupien PJ, Thériault G, Pinault S, Bouchard C: Role of deep abdominal fat in the association between regional adipose tissue distribution and glucose tolerance in obese women. Diabetes 1989;38:304-309.

51 Couillard C, Bergeron N, Prud'homme D, Bergeron $\mathrm{J}$, Tremblay A, Bouchard $\mathrm{C}$, Mauriège $\mathrm{P}$, Després JP: Postprandial triglyceride response in visceral obesity in men. Diabetes 1998;47: 953-960.

52 Abate N, Garg A, Peshock RM, Stray Gundersen J, Grundy SM: Relationships of generalized and regional adiposity to insulin sensitivity in men. J Clin Invest 1995;96:88-98.
53 Marcus MA, Murphy L, Pi-Sunyer FK, Albu JB: Insulin sensitivity and serum triglyceride level in obese white and black women: Relationship to visceral and truncal subcutaneous fat. Metabolism 1999;48:194-199.

54 Goodpaster BH, Thaete FL, Simoneau JA, Kelley DE: Subcutaneous abdominal fat and thigh muscle composition predict insulin sensitivity independently of visceral fat. Diabetes 1997; 46:1579-1585.

55 Williams MJ, Hunter GR, Kekes-Szabo T, Snyder S,Treuth MS: Regional fat distribution in women and risk of cardiovascular disease. Am J Clin Nutr 1997;65:855-860.

56 Frayn KN: Visceral fat and insulin resistance causative or correlative? Br J Nutr 2000; 83(suppl 1):S71-S77.

57 Terry RB, Stefanick ML, Haskell WL, Wood PD: Contributions of regional adipose depots to plasma lipoprotein concentrations in overweight men and women: Possible protective effects of thigh fat. Metabolism 1991;40:733740.

58 Arner P: Catecholamine-induced lipolysis in obesity. Int J Obes Relat Metab Disord 1999; 23(suppl 1):10-13.

59 Jones PR, Edwards DA: Areas of fat loss in overweight young females following an 8-week period of energy intake reduction. Ann Hum Biol 1999;26:151-162.

60 Janssen I, Ross R: Effects of sex on the change in visceral, subcutaneous adipose tissue and skeletal muscle in response to weight loss. Int $\mathrm{J}$ Obes Relat Metab Disord 1999;23:10351046 .

61 Goodpaster BH, Kelley DE, Wing RR, Meier A, Thaete FL: Effects of weight loss on regional fat distribution and insulin sensitivity in obesity. Diabetes 1999;48:839-847.

62 Després J-P, Pouliot M-C, Moorjani S, Nadeau A, Tremblay A, Lupien PJ, Thériault G, Bouchard C: Loss of abdominal fat and metabolic response to exercise training in obese women. Am J Physiol 1991;261:E159-E167.

63 Thomas EL, Brynes A, McCarthy J, Goldstone AP, Hajnal JV, Saeed N, Frost G, Bell JD: Preferential loss of visceral fat following aerobic exercise, measured by magnetic resonance imaging. Lipids 2000;35:769-776.

64 Ashwell M, Lejeune S, McPherson K: Ratio of waist circumference to height may be better indicator of need for weight management. BMJ 1996;312:377.

65 Lean MEJ, Han TS, Morrison CE: Waist circumference as a measure for indicating need for weight management. BMJ 1995;311:158161.

66 Lemieux I, Pascot A, Couillard C, Lamarche B, Tchernof A, Almeras N, Bergeron J, Gaudet D, Tremblay G, Prud'homme D, Nadeau A, Després JP: Hypertriglyceridemic waist: A marker of the atherogenic metabolic triad (hyperinsulinemia; hyperapolipoprotein $\mathrm{B}$; small, dense LDL) in men? Circulation 2000;102: 179-184. 
67 Himsworth HP: Diabetes mellitus. Its differentiation into insulin-sensitive and insulin-insensitive types. Lancet 1936;i:127-130.

68 Rabinowitz D, Zierler KL: Forearm metabolism in obesity and its response to intra-arterial insulin: Evidence for adaptive hyperinsulinism. Lancet 1961;i:690-692.

69 Karam JH, Grodsky GM, Forsham PH: Excessive insulin response to glucose in obese subjects as measured by immunochemical assay. Diabetes 1963;12:197-204.

70 Reaven GM: Role of insulin resistance in human disease. Diabetes 1988;37:1595-1607.

71 Zavaroni I, Bonora E, Pagliari M, Dall'Aglio E, Luchetti L, Buonanno G, Bonati PA, Bergonzani M, Gnudi L, Passeri M, Reaven G: Risk factors for coronary artery disease in healthy persons with hyperinsulinemia and normal glucose tolerance. N Engl J Med 1989;320:702706.

72 Reaven GM, Chen YDI, Jeppesen J, Maheux $\mathrm{P}$, Krauss RM: Insulin resistance and hyperinsulinemia in individuals with small, dense, low density lipoprotein particles. J Clin Invest 1993;92:141-146.

73 Jeppesen J, Hollenbeck CB, Zhou MY, Coulston AM, Jones C, Chen Y-DI, Reaven GM: Relation between insulin resistance, hyperinsulinemia, postheparin plasma lipoprotein lipase activity, and postprandial lipemia. Arterioscler Thromb Vasc Biol 1995; 15:320-324.

74 Alessi MC, Peiretti F, Morange P, Henry M, Nalbone G, Juhan-Vague I: Production of plasminogen activator inhibitor 1 by human adipose tissue: Possible link between visceral fat accumulation and vascular disease. Diabetes 1997;46:860-867.

75 Welborn TA, Wearne K: Coronary heart disease incidence and cardiovascular mortality in Busselton with reference to glucose and insulin concentrations. Diabetes Care 1979;2:154160.

76 Pyöräla K: Relationship of glucose tolerance and plasma insulin to the incidence of coronary heart disease: Results from two population studies in Finland. Diabetes Care 1979;2:131141 .

77 Modan M, Or J, Karasik A, Drory Y, Fuchs Z, Lusky A, Chetrit A, Halkin H: Hyperinsulinemia, sex, and risk of atherosclerotic cardiovascular disease. Circulation 1991;84:1165-1175.
78 Feskens EJ, Kromhout D: Hyperinsulinemia risk factors, and coronary heart disease. The Zutphen Elderly Study. Arterioscler Thromb 1994;14:1641-1647.

79 Fontbonne A, Tchobroutsky G, Eschwege E, Richards JL, Claude JR, Rosselin GE: Coronary heart disease mortality risk: Plasma insulin level is a more sensitive marker than hypertension or abnormal glucose tolerance in overweight males. The Paris prospective study. Int J Obes 1988; 12:557-565.

80 Després JP, Lamarche B, Mauriège $\mathrm{P}$, Cantin B, Dagenais GR, Moorjani S, Lupien PJ: Hyperinsulinemia as an independent risk factor for ischemic heart disease. N Engl J Med 1996; 334:952-957.

81 Tooke JE, Hannemann MM: Adverse endothelial function and the insulin resistance syndrome. J Intern Med 2000;247:425-431.

82 Vogel RA: Coronary risk factors, endothelial function, and atherosclerosis: A review. Clin Cardiol 1997;20:426-432.

83 Patsch JR, Prasad S, Gotto AM Jr, BengtssonOlivecrona G: Postprandial lipemia: A key for the conversion of high density lipoprotein 2 into high density lipoprotein ${ }_{3}$ by hepatic lipase. J Clin Invest 1984;74:2017-2023.

84 Miesenböck G, Patsch JR: Postprandial hyperlipidemia: The search for the atherogenic lipoprotein. Curr Opin Lipidol 1992;3:196-201.

85 Opie LH, Walfish PG: Plasma free fatty acid concentrations in obesity. N Engl J Med 1963; 268:757-760.

86 Reaven GM, Hollenbeck C, Jeng CY, Wu MS, Chen YDI: Measurement of plasma glucose, free fatty acid, lactate, and insulin for $24 \mathrm{~h}$ in patients with NIDDM. Diabetes 1988;37: 1020-1024.

87 Campbell PJ, Carlson MG, Nurjhan F: Fat metabolism in human obesity. Am J Physiol 1994;266:E600-E605.

88 Byrne CD, Wareham NJ, Day NE, McLeish R, Williams DR, Hales CN: Decreased non-esterified fatty acid suppression and features of the insulin resistance syndrome occur in a subgroup of individuals with normal glucose tolerance. Diabetologia 1995;38:1358-1366.

89 Kooner JS, Baliga RR, Wilding J, Crook D, Packard CJ, Banks LM, Peart S, Aitman TJ, Scott J: Abdominal obesity, impaired nonesterified fatty acid suppression, and insulin-mediated glucose disposal are early metabolic abnormalities in families with premature myocardial infarction. Arterioscler Thromb Vasc Biol 1998;18:1021-1026
90 Steinberg HO, Tarshoby M, Monestel R, Hook G, Cronin J, Johnson A, Bayazeed B, Baron AD: Elevated circulating free fatty acid levels impair endothelium-dependent vasodilation. J Clin Invest 1997;100:1230-1239.

91 Lind L, Fugmann A, Branth S, Vessby B, Millgård $\mathrm{J}$, Berne $\mathrm{C}$, Lithell $\mathrm{H}$ : The impairment in endothelial function induced by nonesterified fatty acids can be reversed by insulin. Clin Sci 2000;99:169-174.

92 Calle EE, Thun MJ, Petrelli JM, Rodriguez C, Health CW Jr: Body-mass index and mortality in a prospective cohort of US adults. N Engl J Med 1999;341:1097-1105.

93 Wei M, Kampert JB, Barlow CE, Nichaman MZ, Gibbons LW, Paffenbarger RS Jr, Blair SN: Relationship between low cardiorespiratory fitness and mortality in normal-weight, overweight, and obese men. JAMA 1999;282: 1547-1553.

94 Storlien LH, Higgins JA, Thomas TC, Brown MA, Wang HQ, Huang XF, Else PL: Diet composition and insulin action in animal models. Br J Nutr 2000;83(suppl 1):S85S90.

95 Vessby B: Dietary fat and insulin action in humans. Br J Nutr 2000;83(suppl 1):S91S96.

96 Frost G, Keogh B, Smith D, Akinsanya K Leeds A: The effect of low-glycemic carbohydrate on insulin and glucose response in vivo and in vitro in patients with coronary heart disease. Metabolism 1996;45:669-672.

97 Kaplan NM: The deadly quartet. Upper-body obesity, glucose intolerance, hypertriglyceridemia, and hypertension. Arch Intern Med 1989;149:1514-1520.

98 Landin K, Stigendal L, Eriksson E, Krotkiewski M, Risberg B, Tengborn L, Smith U: Abdominal obesity is associated with an impaired fibrinolytic activity and elevated plasminogen activator inhibitor-1. Metabolism 1990;39:1044-1048.

99 Frayn KN: Adipose tissue and the insulin resistance syndrome. Proc Nutr Soc 2001;60: 375-380.

100 Frayn KN: Metabolic Regulation: Human Perspective, ed 2. Oxford, Blackwell Science, in press. 